\title{
Remaining Innovative: The Role of Past Performance, Absorptive Capacity, and Internationalization
}

\author{
Ivan Lapuente Garrido ${ }^{\dagger}$ \\ Universidade do Vale do Rio dos Sinos - UNISINOS \\ Ronaldo Couto Parente $\Omega$ \\ Fundação Getúlio Vargas - EBAPE \\ Cláudio Reis Gonçalo ${ }^{¥}$ \\ Universidade do Vale do Itajaí \\ Sílvio Luís de Vasconcellos* \\ Universidade do Vale do Itajaí
}

\section{ABSTRACT}

Emerging markets firms are tardy regarding innovativeness and international orientation. Despite that, some of these firms are becoming increasingly competitive regarding innovation and internationalization. It is still unclear how these firms acquire and maintain an innovative capacity. To address this gap we propose and test a framework that integrates the role of past performance as a proxy to investment capacity, realized and potential absorptive capacity and internationalization and their influences on innovativeness, through a survey of 202 Brazilians firms from the Information Technology industry. The results showed the potential and realized absorptive capacity partially mediates the relationship between past performance and innovativeness, and internationalization moderates the relationship between potential absorptive capacity and innovativeness.

Keywords: Innovative capacity, Absorptive capacity, Past performance, Internationalization, Information technology.

\section{INTRODUCTION}

Emerging markets and its firms are latecomers regarding innovativeness (Awate, Larsen \& Mudambi, 2012; Li, Chen \& Shapiro, 2010) and international orientation (Vasilchenko \& Morrish, 2011). Over the past few years, companies from emerging markets have become increasingly innovative (Dhanaraj, 2013) and internationally active (Hsu, Lien, \& Chen, 2013), which has drawn increasing interest from scholarly research. Dhanaraj (2013) points out that there is a research gap on how companies from emerging markets acquire innovative capabilities. In this context, we focus specifically on understanding how companies from a Latin American emerging market increase their innovativeness. To address this goal, we analyzed the role of past performance, absorptive capacity and internationalization on the innovative capacity of Brazilian companies.

The competition based on innovation can contribute to the companies' competitiveness but it is also a risky strategy once involves intensive investments and resource uses. Furthermore the failures rates in innovation are very highs (Barczak et al., 2009; Castellion \& Markham, 2013; Mat \& Razak, 2011). In this study we use the past performance as an investment capacity. It means companies with better past performance can invest more in innovation than companies with worse performance.
Corresponding author:

† Universidade do Vale do Rio dos Sinos - UNISINOS.

E-mail: igarrido@unisinos.br

${ }^{\Omega}$ Fundação Getúlio Vargas - EBAPE.

E-mail: ronaldoparente@gmail.com

${ }^{¥}$ Universidade do Vale do Itajá.

E-mail: claudio.goncalo@univali.br

* Universidade do Vale do Itajaí.

E-mail: silviolvasconcellos@gmail.com

Received: 05/17/2016. Revised: 09/15/2016.

Accepted: 09/28/2016

Published Online: 07/01/2017. 
The absorptive capacity is the organizational capacity to recognize new information or knowledge, assimilate, transform and use them to commercial ends (Cohen \& Levinthal, 1990). In this view, the absorptive capacity can act as a medium to companies explore and exploit knowledge and opportunities (Fernhaber \& Patel, 2012; He \& Wei, 2013). In this study, we propose the absorptive capacity (AC) as a mediator variable between past performance and innovativeness. We adopted the use of the two dimensions of AC - Potential AC and Realized AC (Zahra \& George, 2002). Both dimensions compose the $\mathrm{AC}$; the first supports the second, but they incorporate different capacities. There is still ambiguity about the relationship between potential and realized dimensions (CepedaCarrion, Cegarra-Navarro, \& Jimenez-Jimenez, 2010).

There are mixed results regarding the relationship between firms' innovativeness and internationalization (Kafouros, Buckley, Sharp, \& Wang, 2008). Some studies have usually related internationalization and innovativeness using a direct and static approach (Golovko \& Valentini, 2011; Knight \& Cavusgil, 2004; Ripolles Meliá, Blesa Pérez, \& Roig Dobón, 2010). From a dynamic view, it is necessary to understand how internationalization influences innovativeness. We propose internationalization as a moderator in ACInnovativeness relationship. Moreover, from a largely unexplored perspective, we analyze how innovativeness and performance reinforce each other (Golovko \& Valentini, 2011; Kafouros et al., 2008) where past performance represents the investment capacity.

Our results show the positive influence of the past performance on innovativeness, the partial mediating effect of the two absorptive capacity dimensions on the past performanceinnovativeness relationship and also show the influence of internationalization, as a moderator, on potential absorptive capacity-innovativeness relationship. These findings support the current literature on firm innovation and contribute to a better understanding of the relationship between innovation and: competitive advantage (Kostopoulos, Papalexandris, Papachroni, \& Ioannou, 2011); internationalization (Golovko \& Valentini, 2011; Kafouros et al., 2008) and; absorptive capacity as a capability (Cepeda-Carrion et al., 2010; Rosenbusch, Brinckmann, \& Bausch, 2011).

The paper presents the following sections: Theoretical background and hypotheses where we present our research hypotheses and the theory that supported them, as well as the research framework; Method - where we present the industry and aspects as data collection and treatment; Results - with our findings regarding the hypotheses; and discussion and implications - where we discuss our findings and their contributions to the literature and the practitioners.

\section{THEORETICAL BACKGROUND AND HYPOTHESES}

\subsection{INNOVATIVENESS AND PERFORMANCE VERSUS PAST PERFORMANCE AND INNOVATIVENESS}

Innovativeness is an organizational capacity that reflects the firm tendency to engage and support new ideas, novelty, experimentation and creative processes that may result in innovations (Lumpkin \& Dess, 1996). Innovation is an output of innovativeness; it means the development and implementation of new ideas, products, services and processes to solve problems (Bell, 2005). Innovation can be addressed and conceptualized in a technical or an administrative approach. As a technical view, it originates new products, new services, and process. As an administrative view, it creates new organizational politics (Jiménez-Jiménez \& Sanz-Valle, 2011).

Markets and competition are more dynamic than ever. Products' lifecycles are becoming shorter (Vasilchenko \& Morrish, 2011) while companies are looking for innovations as a way to respond to those changes (Kostopoulos et al., 2011) and to get competitive advantages. In this context, innovativeness promotes changes in both markets and industries and is 
BBR

14,6

561

positively related to superior performance. Innovativeness leads to several outcomes like sales growth due to new products and services, the advantage of the first market entrant, and leverages market share (Kafouros et al., 2008), among others. Innovativeness is one of the most important variables that affect a firm's performance (Mone, McKinley, \& Barker, 1998). Specifically in the case of emerging market firms, scholars have noted that these firms are not only rising in the value chain (Awate et al., 2012) but also are increasing their levels of technological innovativeness through complex technological capabilities (Lamin $\&$ Dunlap, 2011) and patent activities (Gaze \& Roderick, 2012). Moreover, the competition based on innovation requires constant and intensive investments in $R \& D$, people training, information searching, knowledge management improvement and exploration for new opportunities. We highlight two fundamental aspects to keep innovative: the importance of growth or positive performance to keep up investing in innovation and; the unpredictability of the results due to the risks associated with innovation (Barczak et al., 2009; Castellion \& Markham, 2013; Mat \& Razak, 2011).

It is important to note that innovation can be seen as a cyclical and positive process where innovation, growth and performance reinforce each other (Golovko \& Valentini, 2011; Kafouros et al., 2008). We argue companies need to show past positive results to keep investing in innovation, which is in line with the idea of a positive cycle, where innovativeness leads to superior performance; and new investments (from the past performance and growth) lead to innovativeness (Kafouros et al., 2008). Based on that we hypothesize that:

H1: There is a positive and significant relationship between past performance and innovativeness.

\subsection{THE MEDIATING ROLE OF ABSORPTIVE CAPACITY}

The successful development and introduction of innovation depend on companies' resources and capabilities (Rosenbusch et al., 2011) where knowledge is a fundamental aspect to get a competitive advantage. Knowledge management is considered the bottom line to several factors associated with competitiveness, like relationships or networks (Johanson $\&$ Vahlne, 2009) and entrepreneurship (Kostopoulos et al., 2011). Absorptive capacity represents the companies' abilities to identify valuable information and to assimilate and to transform them for commercial purposes. The competence to acquire external knowledge is a critical internal component of the innovation capacity (Cohen \& Levinthal, 1990).

The absorptive capacity improves the organizational capacity to explore external opportunities through new products, or new processes (Fernhaber \& Patel, 2012). Furthermore, identifying and enjoying the benefits of the networks, like new knowledge and opportunities, depends on organizational absorptive capacity (He \& Wei, 2013). According to Zahra and George (2002), absorptive capacity is composed of four capabilities: 1) acquisition: the firm's capability to identify and acquire external knowledge; 2) assimilation: the firm's routines and process to analyze, interpret, and understand acquired information and knowledge; 3) transformation: the firm's capability to create and adjust routines to combine the new and the existing knowledge, and; 4) exploitation: the application of knowledge. They also organized the four capabilities into two dimensions: Potential Absorptive Capacity (PAC), composed by acquisition and assimilation, what makes the firm prone to acquiring and assimilating external knowledge and; Realized Absorptive Capacity (RAC), comprising transformation and exploitation capabilities, what means the firm's capacity to leverage and use of the absorbed knowledge.

Past studies have consistently found high new products failure rates (Barczak, Griffin, \& Kahn, 2009; Castellion \& Markham, 2013; Mat \& Razak, 2011) revealing that not all companies benefit equally from innovation (Kafouros et al., 2008). The simply amount of 
resources isn't a guarantee of innovation success once complexity and risks are inherent in the process. Therefore, the innovation process needs to be managed adequately (Rosenbusch et al., 2011). We expect companies with higher absorptive capacity, in both dimensions PAC and RAC - to be more able to identify, assimilate and exploit new knowledge and opportunities. For these companies, the past result can generate better innovativeness. Thus, we propose the mediating role of absorptive capacity in the past performanceinnovativeness relationship.

A mediating variable transmits the causal effects of the independent variables for dependent and may weaken or even eliminate these effects (Cohen, Cohen, West \& Aiken, 2003; Mackinnon, Lockwood, Hoffman, West \& Sheets, 2002)

H2a: The potential absorptive capacity (PAC) mediates the relationship between past performance and innovativeness;

$\mathrm{H} 2 \mathrm{~b}$ : The realized absorptive capacity (RAC) mediates the relationship between past performance and innovativeness.

\subsection{THE ROLE OF INTERNATIONALIZATION}

The relationship between internationalization and innovativeness is still not very clear (Kafouros et al., 2008). International development and innovativeness seem to reinforce each other since acting abroad improve the firms' innovativeness capacity, while innovativeness leads firms to the development of new products, services, and processes that increase firms' participation in international markets (Golovko \& Valentini, 2011). If on the one hand innovativeness facilitates the acquisition of knowledge and promotes capabilities, leading companies to enter into new markets (Knight \& Cavusgil, 2004), on the other hand, internationalized firms deal with new resources, networks, and environments that facilitate or promote innovativeness. Following these arguments, we propose that internationalization has a direct relationship with innovativeness.

H3: Firm's Internationalization has a direct and positive relationship with innovativeness.

Moreover, despite the importance of the internationalization-innovativeness relationship, there's still a dearth of research on how specifically having international operations improves innovation development (Un, 2011). From a dynamic approach, we believe the effect occurs through firms' capabilities since, according to Golovko and Valentini (2011), internationalization and success in international markets are related to the internal organization's capacity to support their innovating process. Companies acting in international markets face to a more complex environment. This exposition can improve the quality of decisions and the access to new resources, improving organizational capabilities (Kostopoulos et al., 2011), such as absorptive capacity and innovativeness. Internationalization influences and is influenced by knowledge and learning (Welch \& Welch, 1996).

Moderating variables are those that modify the strength and / or direction of a relationship between an independent variable and a dependent (Cohen, et al., 2003).

Based on that we propose:

H3a: Internationalization moderates the potential absorptive capacity-innovativeness relationship;

Furthermore from the new resources and environments, internationalized companies can identify new opportunities from the foreign relationships established with global stakeholders (Johanson \& Vahlne, 2009). It can be an opportunity to leverage and apply the absorbed knowledge. Thus, we propose:

$H 3 b$ : Internationalization moderates the realized absorptive capacity-innovativeness relationship.

Following the proposed hypotheses, we present the research framework (Figure 1). 
BBR

14,6

563

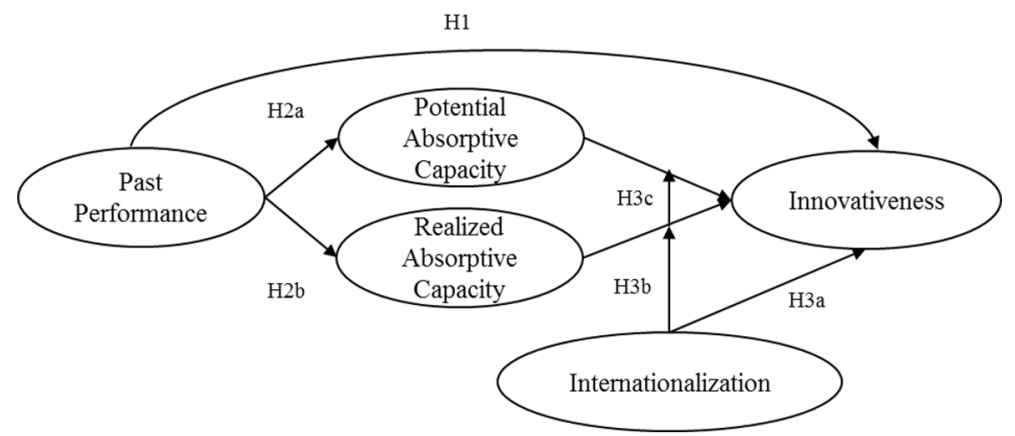

Figure 1. Research Framework

\section{METHOD}

The research framework was tested based on cross-sectional data from Brazilian Information Technology (IT) companies. We analyzed the data through OLS regression analysis.

\subsection{EMPIRICAL CONTEXT}

We chose The Brazilian IT industry for this study due to its characteristics of high speed in innovations introduction, high competitiveness, and knowledge intensity. According to Brazil IT ${ }^{+}$(2013), the Brazilian IT industry evolution started with the Brazilian economic opening in the 1990s. At that time, the Brazilian environmental diversity and the needs for products customization to attend to the new business demand for specific knowledge about the Brazilian market led to significant growth in the IT industry.

The Brazilian IT industry encompasses microelectronics, telecommunications, hardware, and software. It consists of more than 70.000 companies and generates about1.3 million jobs (IBGE, 2012). The industry produces around $\$ 110$ billion (U.S.) per year. It means 5.4 percent of the Brazilian Gross National Product. The industry has been growing more than 11 percent per year in the last five years. Regarding attracting international investments to the IT Industry, Brazil is the fifth country in the world and the second among the emerging economies and the Brazilian IT industry exports around \$3 billion (U.S.) per year.

\subsection{DATA COLLECTION}

We collected the data between September 2013 and March 2014. We contacted the companies, from a list of 6.800 firms from a commercial agency, by phone inviting them to take part in the research. The respondents were executives responsible for the strategic planning. We conducted a pretest with 28 companies to verify the questionnaire quality. The tests allowed verifying the scales, correlation among variables and questionnaires answering time. We made only a few modifications regarding writing some sentences. The questionnaire was built and applied in Portuguese. An English version is in the appendix.

A sample of 216 companies answered the questionnaire; we eliminated 14 due to nonresponse data, resulting in 202 companies. Among these companies, 27 are internationalized while the others act only in the domestic market. Overall, this sample reflects the huge diversity of the Brazilian IT industry. The experience average is 6.9 years, but within the large range, from 1 to 40 years. The companies' average size is 20.77 employees within the range from 1 to 1200 . We can observe the strong dispersion through the standard deviation. Among internationalized companies the experience average is 14.6 years and the average time of international operations is 7.3 years. Table 1 summarizes the sample data. 
Table 1. Sample summary

\begin{tabular}{lcc}
\hline & Average & Standard Deviation \\
\hline Experience (EX -age/years) & 6.90 & 6.59 \\
Size (SZ - employees) & 20.77 & 90.04 \\
Potential Absorptive Capacity (PAC) & 4.50 & 0.59 \\
Realized Absorptive Capacity (RAC) & 4.38 & 0.64 \\
Innovativeness (IN) & 4.33 & 0.68 \\
Past performance (PP) & 4.36 & 0.74 \\
\hline
\end{tabular}

\subsection{MEASURES}

We selected measures previously used in the literature in all of the scales. The detailed measurements of all constructs are in the appendix.

\subsubsection{DEPENDENT VARIABLE}

Innovativeness (IN): Several studies from secondary and objective data have utilized some proxies to capture innovation, like the number of patents (Anokhin \& Wincent, 2011; C. Kim \& Park, 2010), new products and process (Cassiman \& Golovko, 2010) and investment in R\&D (Kim, Park, \& Lee, 2013). In studies from primary and subjective data, the innovativeness scales have tried to capture dimensions related to new products, process, and innovation capacity. Bell (2005) utilizes new products, new process, and adoption of new technologies to measure innovativeness. Jiménez-Jiménez and Sanz-Valle (2011) use a tridimensional scale encompassing products and services, process, and administrative innovations capturing the number of innovation, and the organizational propensity to innovate. Dess, Lumpkin, and Covin (1997) and Lumpkin and Dess (1996) explores the innovative capacity, the training and stimulus to innovate, the environment and innovation valorization by the company, as well the adoption of new products and process. In line with these studies, we adopted a 5-point concordance scale composed initially of 9 questions focusing on the respondents' perception of the organizational innovative capacity.

\subsubsection{INDEPENDENT VARIABLES}

Absorptive capacity $(A C)$ : The AC is the mediating variable on the past performanceinnovativeness relationship. In agreement with the $\mathrm{AC}$ concept, we adopted its two dimensions: a) Potential absorptive capacity, composed of acquisition and assimilation capacity, and; b) Realized Absorptive Capacity, composed by transformation and use of knowledge. A 5-point concordance scale, based on Jansen, Bosch, Volberda, and Volberda, (2005); and (Cohen \& Levinthal, 1990).

Internationalization (IT): In this research, we are not focusing on internationalization as a process, or in the international strategy adopted by companies, but just in the possible consequences of the internationalization. We verified if the company is or isn't acting abroad using a categorical variable $(0=$ not internationalized; $1=$ internationalized $)$.

We tested the effect of the internationalization as a dependent variable to innovativeness and as moderating variable on the relationship between AC and IN. 
BBR

14,6

565

Past performance $(P P)$ has been evaluated by two approaches: objective data, like return on investments or sales volume (Katsikeas, Samiee, \& Theodosiou, 2006; Tanriverdi $\&$ Venkatraman, 2005), and on subjective evaluations from the respondents' perceptions (Zou, Taylor, \& Osland, 1998).

In this study, we adopted subjective data, capturing the respondents' perceptions about performance. We choose this method because we are researching companies from an emerging country (Brazil) and an industry with a large difference among companies. Companies under these conditions tend to present difficulties in delivering objective data, especially related to past performance. Moreover, we used a temporal criterion to the performance indicators. Following the general indicators from the EXPERF scale (Zou et al., 1998), we adopted a 5-point concordance scale about the past three years' performance regarding sales, productivity, competitive positioning and market share.

Control variables: The companies' experience (company age) and the size (number of employees) are the control variables in the study. The experience (EX) leads to a bigger commitment to the market and learning (Johanson \& Vahlne, 2003). The company size (SZ) is related with the potential to access resources and develop capacities. Small and medium companies normally show fewer resources access and capabilities when compared with big companies (Musteen, Francis, \& Datta, 2010).

Due to the high dispersion and the large range observed in companies' size and experience (see Table 1) we recode each of them in five categories: size - (1.) 0 to 3 employees, (2.) 4 to 5 employees, (3.) 6 to 8 employees, (4.) 9 to 15 employees and (5.) more than 15 employees; experience (1.) 0 to 2 years, (2.) 3 to 4 years, (3.) 5 to 7 years, (4.) 8 to 12 years and (5.) more than 12 years.

\subsection{MEASUREMENT VALIDATION AND ANALYTICAL PROCEDURES}

To test the hypotheses, we employed regression analysis through four models. The data collected was previously evaluated and treated. From a descriptive analysis, 14 questionnaires were eliminated for presenting missing values larger than 5 percent of a variable or a respondent (Kline, 1998). Beyond that, eight questionnaires with missing values lower than 5 percent had the data replaced by the average. We verified the normality via the kurtosis and the skewness analysis (Kline, 1998), and outliers and linearity through the graphic inspection.

\subsection{CONSTRUCTS VALIDITY}

Each construct was evaluated individually following the confirmatory factorial analysis (CFA). Table 2 presents the fitness index obtained in the CFA, the composed reliability (CR), extracted variance (EV), Cronbach's alpha (CA) and also the range of the factorial loading (FL) between the indicators and the respective construct.

The data shows that the constructs have an adequate reliability. The adjustment index from the CFA meets the general literature recommendation (Hair, Black, Anderson \& Tatham, 2005), the Cronbach alpha's results are superior to 0.7 as recommended by Nunnally and Berstein (1978) and Mendelson and Pillai (1999), the composed reliability results are superior to 0.7 , and the extracted variance is adequate to the past performance (bigger than 0.5 ), but it is below 0.5 to innovation and absorptive capacity (Hair et al., 2005). 
Table 2. Constructs reliability

\begin{tabular}{lcccc}
\hline $\begin{array}{l}\text { Constructs } \\
\text { Indicators }\end{array}$ & & $(\mathrm{IN})$ & $(\mathrm{AC})$ & $(\mathrm{PP})$ \\
\hline & $\mathrm{X} / \mathrm{DF}$ & 1.87 & 1.93 & 2.56 \\
& $\mathrm{p}$ & 0.06 & 0.00 & 0.04 \\
& $\mathrm{GFI}$ & 0.97 & 0.96 & 0.98 \\
Fitness index & AGFI & 0.93 & 0.92 & 0.92 \\
(CFA) & $\mathrm{NFI}$ & 0.97 & 0.94 & 0.98 \\
& TLI & 0.97 & 0.95 & 0.97 \\
& CFI & 0.98 & 0.97 & 0.99 \\
& RMSEA & 0.06 & 0.07 & 0.09 \\
\hline CR & & 0.84 & 0.853 & 0.89 \\
EV & & 0.46 & 0.423 & 0.62 \\
CA & & 0.84 & 0.854 & 0.88 \\
Indicators & & 6 & 8 & 5 \\
FL & & 0.67 to 0.75 & 0.56 to 0.73 & 0.57 to 0.87 \\
\hline
\end{tabular}

Innovativeness (IN); Potential absorptive capacity (PAC);

Realized absorptive capacity (RAC); Past performance (PP);

Composite Reliability (CR); Extracted Variance (EV),

Cronbach's Alpha (CA); Factorial Loads (FL).

To address the discriminant validity of constructs we analyzed the correlation between constructs (Bagozzi, Yi, \& Phillips, 1991). The correlations between every two constructs must be statistically different than 1 to indicate the discriminant validity (Schmitt \& Stults, 1986). The results show all pairs of constructs with high correlations meet these parameters at $\mathrm{p}<0.05$.

The questionnaire and the correlation matrix between constructs are in the appendix.

Since we collected data from just one respondent in each company, we conducted the Harman's one-factor test to address the common method variance (Podsakoff, MacKenzie, Lee, \& Podsakoff, 2003). The one-factor found has explained less than 50 percent (40.54) of the covariance in variables, which indicates there isn't a serious problem of common method variance. Once the data and constructs are adequate, we tested the proposed hypotheses.

\section{RESULTS}

Before the hypotheses test, we used the confirmatory factor analyzes (CFA) to access the adjustment index of the complete model. We found results that showed good adjustment of the model: Chi-square/Degrees of freedom (1.73); $\mathrm{p}(<0.05)$; GFI (0.89); AGFI (0.87); NFI (0.88); TLI (0.94); CFI (0.95), and; RMSEA (0.05). The hypotheses were addressed using regression analysis. We tested four different models.

Model I analyzed the direct relationship between past performance and innovativeness; Model II analyzed the relationship between absorptive capacity (PAC and RAC) and innovativeness; Model III tested the absorptive capacity as a mediating variable between past performance-innovativeness relationship, and in Model IV we included the internationalization as a moderating variable on the absorptive capacity-innovativeness relationship and as an independent variable to innovativeness. Table 3 presents the results of the regression analysis. 


\begin{tabular}{|c|c|c|c|c|}
\hline & $\begin{array}{l}\text { Model I } \\
\text { PP-IN } \\
\text { SZ EX }\end{array}$ & $\begin{array}{c}\text { Model II } \\
\text { PAC/RAC-IN } \\
\text { SZ EX }\end{array}$ & $\begin{array}{c}\text { Model III } \\
\text { PP PAC RAC IN SZ EX }\end{array}$ & $\begin{array}{c}\text { Model IV } \\
\text { PP AC IN } \\
\text { IT IT*AC } \\
\text { SZ EX }\end{array}$ \\
\hline $\mathrm{R} 2$ & 0.38 & 0.49 & 0.55 & 0.57 \\
\hline $\mathrm{F}$ & $40.78^{* *}$ & $47.00^{* *}$ & $47.99^{* *}$ & $32.24^{* *}$ \\
\hline R2 CHAN & & & $0.17^{* *}$ & $0.19^{* *}$ \\
\hline F CHAN & & & $36.73^{* *}$ & $17.14^{* *}$ \\
\hline Beta PP & $0.58^{* *}$ & & $0.30^{* *}$ & $0.30^{* *}$ \\
\hline Beta SZ & $0.10^{*}$ & & $0.08^{*}$ & $0.09^{* *}$ \\
\hline Beta EX & -0.73 & & -0.03 & -0.36 \\
\hline Beta PAC & & $0.27^{* *}$ & $0.21^{* *}$ & $0.18^{* *}$ \\
\hline VIF PAC & & & 1.39 & 1.39 \\
\hline Beta RAC & & $0.44^{* *}$ & $0.37^{* *}$ & $0.31^{* *}$ \\
\hline VIF RAC & & & 1.44 & 1.44 \\
\hline Beta IT & & & & -0.05 \\
\hline Beta IT*PAC & & & & $0.22^{* *}$ \\
\hline VIF IT*PAC & & & & 1.02 \\
\hline Beta IT*RAC & & & & -0.10 \\
\hline VIF IT*RAC & & & & 1.03 \\
\hline
\end{tabular}

The analysis of variance inflation factors (VIF) showed values below 1.5, far below of the threshold of 10 pointed out as the acceptable limit according to Kleinbaum, Kupper and Muller (1988). Model I supported the Hypothesis $1(\mathrm{bPP}=0.58, \mathrm{p}<0.05)$. There is a direct and significant relationship between past performance and innovativeness. But, according to the results of Model III $(b P P=0.30, p<0.05 ; b P A C=0.27, p<0.05 ; b R A C=0.44$, $\mathrm{p}<0.5$ ), this relationship is partially mediated by the absorptive capacity considering its two dimensions - potential and realized. To confirm the mediation of absorptive capacity we used the Sobel test. The obtained p-value was 0.00 , confirming the significant mediator effect (the Sobel test result is in the appendix).

The inclusion of the absorptive capacity (PAC and RAC) as a mediating variable between $\mathrm{PP}$ and IN has improved the variance explained in the model I in 43.98 percent (R2 change $=0.11$ between Model I and III). The results support the Hypotheses $2 \mathrm{a}$ and $2 \mathrm{~b}$ that argue the relationship between past performance and innovativeness is mediated by potential and realized absorptive capacity. We find a partial mediating effect. The third hypothesis proposed the relationship between internationalization and innovativeness. We suggested a direct relationship with innovativeness $(\mathrm{H} 3 \mathrm{a})$ and the moderation between absorptive capacity and innovativeness $(\mathrm{H} 3 \mathrm{~b}$ and $\mathrm{H} 3 \mathrm{c})$. To test this hypothesis a dummy variable was created to characterize companies' internationalization. We also created two variables to capture the interaction between absorptive capacity and internationalization (IT*PAC and IT*RAC). We centered the variables from their averages to avoid collinearity effects. However, the results (Model IV) didn't support hypotheses H3 (the direct relationship between internationalization and innovativeness, and $\mathrm{H} 3 \mathrm{~b}$ (the moderator effect on RACIN), but supported H3a (the moderator effect on PAC-IN). Figure 2 offers a graphic with a visual perspective of the moderator effect of internationalization on realized absorptive capacity-innovativeness relationship. 


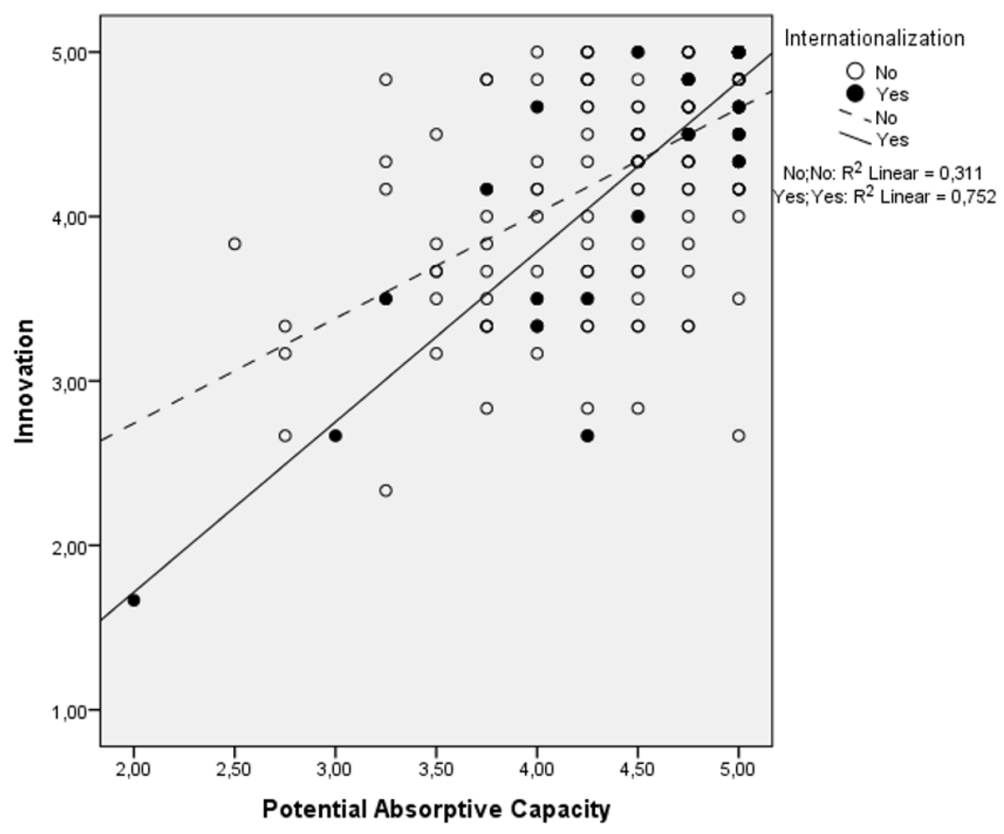

Figure 2. The moderator effect of internationalization

The graphic shows the relationship between potential absorptive capacity and innovativeness is stronger when moderated by internationalization $(0.75 \mathrm{R}$-squared with moderation against $0.31 \mathrm{R}$-squared without moderation). The companies' size has a positive influence on the proposed model. The companies' experience didn't show a significant result, but it is important to highlight the negative relation showed in the results in the model I, III and IV.

\section{DISCUSSION AND IMPLICATIONS}

We have focused on improving the understanding of how to remain innovative once innovativeness is crucial to the long-term success of emerging market firms. We believe our study contributes to the innovation literature by offering a dynamic view of the theme, investigating the role of past performance, potential and realized absorptive capacity and internationalization. We proposed an alternative and underexplored path to explain innovativeness. Our model presents two fundamental characteristics that differentiate it from current studies: it uses past performance as an independent variable and innovativeness as the dependent, and it offers a dynamic approach when including absorptive capacity (in it both, potential and realized dimensions) and the internationalization in an integrative framework. Specifically, the study contributes to three points: 1.) the role of past performance on innovativeness; 2.) the role of potential and realized absorptive capacity on past performance-innovativeness relationship, and 3.) the role of internationalization in innovative capacity.

Past performance and innovativeness: The positive and significant result, despite the nontraditional approach we used, is in line with the idea of an existing reinforcement between innovation and performance. Past performance is a significant condition for a company to remain innovative. It can mean new or higher investments. Innovativeness is important to achieve competitive advantage, but past performance is crucial to improving the companies' innovativeness. This result indicates companies with higher performance probably reinvest their results to remain innovative and profitable. Thus, our results contribute to demonstrate that innovativeness needs to be adequately managed to avoid the 
BBR

14,6

risks and the complexity inherent to the innovation process (Rosenbusch et al., 2011). Thus, to address a better comprehension about how to remain innovative and how to improve the innovativeness management, our model has analyzed the role of absorptive capacity and internationalization.

Absorptive capacity: Knowledge and learning are two fundamental aspects of supporting innovation (Verona, 1999). From them, companies can better explore and exploit opportunities (Cohen \& Levinthal, 1990; Fernhaber \& Patel, 2012), learn about its failures in innovation (Magazzini et al., 2012) and generate innovations (Sinkula, Baker, \& Noordewier, 1997). Researchers already have indicated absorptive capacity has a positive influence on performance (Tseng, Pai, \& Hung, 2011), but our result about the role of absorptive capacity improves this view, addressing a dynamic approach to the relationship and including the different dimensions of absorptive capacity.

Following the dynamic capabilities premise, our proposal has included the absorptive capacity in the model under the argument that companies have a different capacity to explore and exploit opportunities. The result has pointed out both potential and realized absorptive capacity partially mediate the past performance-innovativeness relationship. It means companies presenting a higher level of PAC and RAC are better prepared to acquire, assimilate, transform and use knowledge, and this capacity mediates the relationship between past performance and innovativeness, acting as a mechanism of quality control. The potential absorptive capacity is related to the companies' capacity to acquire and assimilate external knowledge; it is important to help companies access and disseminate the right information into the firm. The realized absorptive capacity dimension is related to transformation and use of the knowledge, what is important to combine internal and external knowledge and its application to seize new opportunities. Therefore, our model advanced current research on innovation development by evidencing the fundamental role of potential and realized absorptive capacity as elements of competitive advantage. The PAC and RAC act as a differential leading the investments (or the past performance) to innovativeness and probably too effective innovation.

Our results also highlight the limitation of past research that used proxies like R\&D expenditures to capture innovation or innovative capacity. Bigger investments do not guarantee effective innovation. These types of measures don't capture the quality and assertiveness of the innovations. Thus, we suggest the inclusion of effectiveness innovation measures control in the research related to innovativeness.

Internationalization: to further understand how to remain innovative, this study also contributes to the knowledge of how internationalization plays a role on innovativeness (Kafouros et al., 2008). Despite our expectation based on literature indications, we didn't find a direct relationship between internationalization and innovativeness. Probably this is because a direct relationship represents a static view and don't capture the real nature of the relation. To avoid this problem and to broaden the spectrum studied we also proposed a moderating effect of the internationalization on absorptive capacity-innovativeness relationships. As we believed and proposed in the hypotheses $\mathrm{H} 3 \mathrm{~b}$ and $\mathrm{H} 3 \mathrm{c}$, the influence of internationalization on innovativeness occurs through an indirect path.

The moderating effect of the internationalization is positive on the realized absorptive capacity and innovativeness relationship. The gains from the internationalization, like learning, networks, access to new resources, among others (Kostopoulos et al., 2011; Welch \& Welch, 1996) can improve the companies' capacity to acquire and assimilate external knowledge that will lead to innovativeness. Surprisingly, we didn't find a moderator effect of the internationalization on realized-innovativeness relationship. We suggest two explanations for it. First, because the transformation and use of knowledge represent capacities inherent to the companies, independently of the market or location that companies are exploring. Second, because the realized dimension is a consequence of the potential dimension and in 
this case, the influence is positive in the acquisition and assimilation capabilities due to the access to new information and resources from the international environment. An alternative explanation could be methodological. We addressed internationalization as a categorical variable. It doesn't allow capturing the international involvement level. Maybe companies with foreign direct investments can show different behavior from companies with exporting activities.

\subsection{MANAGERIAL CONTRIBUTIONS AND LIMITATIONS}

Under the managerial approach, the main contributions of this study are the key role of the absorptive capacity and internationalization to understand innovativeness. The results show that companies can benefit from investing in improving their absorptive capacity and acting abroad. From the AC, companies can better explore and exploit knowledge and opportunities, improve the quality of their investments in innovativeness. It can be seen as a path to get success and to reduce failures. Furthermore, companies can access new resources and knowledge through internationalization, improving the AC-innovativeness relationship. From the combination of absorptive capacity and internationalization, companies can improve and qualify their investments, remain innovative and keep a positive cycle, as proposed by (Kafouros et al., 2008).

This study presents some limitations. We didn't control the industry effect, once we focused only one industry. The past performance, despite its temporal characteristic, is not a longitudinal measurement, we trusted in the respondent perception to evaluate the companies' past results. The respondent companies are relatively young, with an average age of 6.9 years, which may affect the ability to evaluate past performance. Finally, the internationalization was evaluated from a categorical variable what doesn't capture different levels of companies' internationalization.

Considering the results and the limitations, we suggest future research should incorporate different industries and different methods to capture internationalization degree. Past performance should be measured using objective data or a longitudinal approach. We also recommend, despite our care with the method, to collect data from more than one respondent per company and the complementary use of objective data to access performance, avoiding possible problems regarding common method variance.

\section{REFERENCES}

Anokhin, S., \& Wincent, J. (2011). Start-up rates and innovation: A cross-country examination. Journal of International Business Studies, 43(1), 41-60. doi:10.1057/jibs.2011.47

Awate, S., Larsen, M. M., and Mudambi, R. 2012. EMNE catch-up strategies in the wind turbine industry: Is there a trade-off between output and innovation capabilities? Global Strategy Journal 2(3): 205-223.

Bagozzi, R., Yi, Y., \& Phillips, L. (1991). Assessing construct validity in organizational research. Administrative Science Quarterly, 36, 421-458.

Barczak, G., Griffin, A., \& Kahn, K. B. (2009). PERSPECTIVE: Trends and Drivers of Success in NPD Practices: Results of the 2003 PDMA Best Practices Study *. Journal of Product Innovation Management, 26(1), 3-23. doi:10.1111/j.1540-5885.2009.00331.x

Barney, J. (1991). Firm resources and sustained competitive advantage. Journal of Management, 17(1), 99120.

Bell, G. G. (2005). Clusters, networks, and firm innovativeness. Strategic Management Journal, 26(3), 287295. doi: $10.1002 / \mathrm{smj} .448$

BRASIL IT PLUS. Available in < http://www.apexbrasil.com.br/brasilit/>. Accessed in 05/20/2013.

Cassiman, B., \& Golovko, E. (2010). Innovation and internationalization through exports. Journal of International Business Studies, 42(1), 56-75. doi:10.1057/jibs.2010.36

Castellion, G., \& Markham, S. K. (2013). Perspective: New Product Failure Rates: Influence of Argumentum ad Populum and Self-Interest. Journal of Product Innovation Management, 30(5), 976-979. doi:10.1111/ j.1540-5885.2012.01009.x 
BBR

14,6
Cepeda-Carrion, G., Cegarra-Navarro, J. G., \& Jimenez-Jimenez, D. (2010). The Effect of Absorptive Capacity on Innovativeness: Context and Information Systems Capability as Catalysts. British Journal of Management, 23, no-no. doi:10.1111/j.1467-8551.2010.00725.x

Cohen, J.; Cohen, P.; West, S. G.; Aiken, L. S. (2003) (Third Edition) Applied Multiple Regression / Correlation Analysis for the Behavioral Sciences. Routledge Taylor \& Francis Group. New York.

Cohen, W. M., \& Levinthal, D. A. (1990). Absorptive Capacity: A New Perspective on Learning and Innovation. Administrative Science Quarterly, 35(1), 128-152. doi:10.2307/2393553

Dess, G., Lumpkin, G. T., \& Covin, J. G. (1997). Entrepreneurial strategy making and firm performance: Tests of contingency and configurational models. Strategic Management ..., 18(9), 677-695.

Dhanaraj, C. (2013). Innovative firms in emerging market countries. Journal of International Business Studies, 44(8), 864-866. doi:10.1057/jibs.2013.51

Drnevich, P., \& Kriauciunas, A. (2011). Clarifying the conditions and limits of the contributions of ordinary and dynamic capabilities to relative firm performance. Strategic Management Journal, 279(July 2010), 254-279. doi:10.1002/smj

Fernhaber, S., \& Patel, P. (2012). How do young firms manage product portfolio complexity? The role of absorptive capacity and ambidexterity. Strategic Management Journal, 1539(July 2010), 1516-1539. doi:10.1002/smj

Gaze, L., and Roderick, J. 2012. The Grown Up BRIC: Innovation and Brand Expansion in Brazil. New York: Thomson Reuters.

Golovko, E., \& Valentini, G. (2011). Exploring the complementarity between innovation and export for SMEs' growth. Journal of International Business Studies, 42(3), 362-380. doi:10.1057/jibs.2011.2

Hampshire, N., \& Wiley, J. (2010). RESEARCH NOTES AND COMMENTARIES INNOVATION OBJECTIVES , KNOWLEDGE SOURCES , 236(January 2007), 224-236. doi:10.1002/smj

He, X., \& Wei, Y. (2013). Export market location decision and performance: The role of external networks and absorptive capacity. International Marketing Review, 30(6), 559-590. doi:10.1108/IMR-09-2011-0232

Hernandez-Espallardo, M., Molina-Castillo, F.-J., \& Rodriguez-Orejuela, A. (2012). Learning processes, their impact on innovation performance and the moderating role of radicalness. European Journal of Innovation Management, 15(1), 77-98. doi:10.1108/14601061211192843

Hsu, C.-W., Lien, Y.-C., \& Chen, H. (2013). International ambidexterity and firm performance in small emerging economies. Journal of World Business, 48(1), 58-67. doi:10.1016/j.jwb.2012.06.007

IBGE, Instituto Brasileiro de Geografia e Estatística. Available in $<$ http://www.ibge.gov.br $>$. Accessed in: August $/ 2013$.

Jansen, J. J. P., Bosch, F. A. J. Van Den, \& Volberda, H. W. (2005). MANAGING POTENTIAL AND REALIZED ABSORPTIVE CAPACITY : HOW DO ORGANIZATIONALANTECEDENTS MATTER ?, 48(6), 999-1015.

Jiménez-Jiménez, D., \& Sanz-Valle, R. (2011). Innovation, organizational learning, and performance. Journal of Business Research, 64(4), 408-417. doi:10.1016/j.jbusres.2010.09.010

Johanson, J., \& Vahlne, J. (2003). Business relationship learning and commitment in the internationalization process. Journal of International Entrepreneurship, 1(Mar 2003), 83-101.

Johanson, J., \& Vahlne, J. (2009). The Uppsala internationalization process model revisited: From liability of foreignness to liability of outsidership. Journal of International Business ..., 40(9), 1411-1431. doi:10.1057/jibs.2009.24

Kafouros, M. I., Buckley, P. J., Sharp, J. a., \& Wang, C. (2008). The role of internationalization in explaining innovation performance. Technovation, 28(1-2), 63-74. doi:10.1016/j.technovation.2007.07.009

Katsikeas, C., Samiee, S., \& Theodosiou, M. (2006). STRATEGY FIT AND PERFORMANCE CONSEQUENCES OF INTERNATIONAL MARKETING STANDARDIZATION. Strategic Management ..., 890(February 2003), 867-890. doi:10.1002/smj

Kim, C., \& Park, J. (2010). The Global Research-and-Development Network and Its Effect on Innovation. Journal of International Marketing, 18(4), 43-57.

Kim, H., Park, N. K., \& Lee, J. (2013). How does the second-order learning process moderate the relationship between innovation inputs and outputs of large Korean firms? Asia Pacific Journal of Management, 31(1), 69-103. doi:10.1007/s10490-013-9352-x

Knight, G. a, \& Cavusgil, S. T. (2004). Innovation, organizational capabilities, and the born-global firm. Journal of International Business Studies, 35(2), 124-141. doi:10.1057/palgrave.jibs.8400071

Kleinbaum, D. G., Kupper, L. L., and Muller, K. E. 1988. Applied regression analysis and other multivariate analysis methods. Boston: PWS-Kent Publishing Company. 
KLINE, Rex B. (1998) Principle and practice of structural equation modeling. New York: The Guilford Press.

Kostopoulos, K., Papalexandris, A., Papachroni, M., \& Ioannou, G. (2011). Absorptive capacity, innovation, and financial performance. Journal of Business Research, 64(12), 1335-1343. doi:10.1016/j. jbusres.2010.12.005

Lamin, A., and Dunlap, D. 2011. Complex technological capabilities in emerging economy firms: The role of organizational relationships. Journal of International Management 17(3): 211-228.

Lee, L., \& Sukoco, B. (2011). Risk-Taking as a Moderator of the Effect of Team Reflexivity on Product Innovation: An Empirical Study. International Journal of Management, 28(4), 263-275.

Li, J., Chen, D., and Shapiro, D. M. 2010. Product innovations in emerging economies: The role of foreign knowledge access channels and internal efforts in Chinese firms. Management and Organization Review 6(2): 243-266

Lumpkin, G. T., \& Dess, G. G. (1996). Clarifying the Entrepreneurial Orientation Construct and Linking It to Performance. The Academy of Management Review, 21(1), 135. doi:10.2307/258632

Mackinnon, D.P.; Lockwood, C.M.; Hoffman, J.M.; West, S.G.; Sheets, V. (2002) A comparison of methods to test mediation and other intervening variable effects. Psychological Methods, Mahwah, v.7, n.1, p.83-104.

Magazzini, L., Pammolli, F., \& Riccaboni, M. (2012). Learning from Failures or Failing to Learn? Lessons from Pharmaceutical R\&D. European Management Review, 9(1), 45-58. doi:10.1111/j.17404762.2012.01027.x

Mat, A., \& Razak, R. (2011a). The Influence of Organizational Learning Capability on Success of Technological Innovation ( Product ) Implementation with Moderating Effect of Knowledge Complexity. Int. J. Bus. Soc. Sci, 2(17), 217-226.

Mendelson, H., \& Pillai, R. R. (1999). Industry Clockspeed: Measurement and Operational Implications. Manufacturing \& Service Operations Management, 1(1), 1-20. doi:10.1287/msom.1.1.1

Mone, M. a., McKinley, W., \& Barker, V. L. (1998). Organizational Decline and Innovation: A Contingency Framework. The Academy of Management Review, 23(1), 115. doi:10.2307/259102

Musteen, M., Francis, J., \& Datta, D. K. (2010). The influence of international networks on internationalization speed and performance: A study of Czech SMEs. Journal of World Business, 45(3), 197-205. doi:10.1016/j. jwb.2009.12.003

Nunnally, J. C., and Bernstein, I. 1978. Psychometry Theory. New York: McGraw-Hill.

Podsakoff, P. M., MacKenzie, S. B., Lee, J.-Y., \& Podsakoff, N. P. (2003). Common method biases in behavioral research: a critical review of the literature and recommended remedies. The Journal of Applied Psychology, 88(5), 879-903. doi:10.1037/0021-9010.88.5.879

Ripolles Meliá, M., Blesa Pérez, A., \& Roig Dobón, S. (2010). The influence of innovation orientation on the internationalization of SMEs in the service sector. The Service Industries Journal, 30(5), 777-791. doi:10.1080/02642060802342679

Rosenbusch, N., Brinckmann, J., \& Bausch, A. (2011). Is innovation always beneficial? A meta-analysis of the relationship between innovation and performance in SMEs. Journal of Business Venturing, 26(4), 441-457. doi:10.1016/j.jbusvent.2009.12.002

Salomon, R., \& Jin, B. (2010). Do leading or lagging firms learn more from exporting? Strategic Management Journal, 31(10), 1088-1113. doi:10.1002/smj.850

Schmidt, J. B., Sarangee, K. R., \& Montoya, M. M. (2009). Exploring New Product Development Project Review Practices. Journal of Product Innovation Management, 26(5), 520-535. doi:10.1111/j.15405885.2009.00678.x

Schmitt, N., \& Stults, D. M. (1986). Methodology Review: Analysis of Multitrait-Multimethod Matrices. Applied Psychological Measurement, 10(1), 1-22. doi:10.1177/014662168601000101

Sinkula, J., Baker, W., \& Noordewier, T. (1997). A framework for market-based organizational learning: linking values, knowledge, and behavior. Journal of the Academy of ..., 25(4), 305-318.

Tanriverdi, H., \& Venkatraman, N. (2005). Knowledge relatedness and the performance of multibusiness firms. Strategic Management Journal, 26(2), 97-119. doi:10.1002/smj.435

Teece, D. J. (2012). Dynamic Capabilities: Routines versus Entrepreneurial Action. Journal of Management Studies, 49(8), 1395-1401. doi:10.1111/j.1467-6486.2012.01080.x

Teece, D. J. (2014). A dynamic capabilities-based entrepreneurial theory of the multinational enterprise. Journal of International Business Studies, 45(1), 8-37. doi:10.1057/jibs.2013.54

Terziovski, M. (2010). Commentaries Innovation Practice and its Performance Implications in Small and Medium Enterprises (SMES) in the Manufacturing Sector: A Resource-. Strategic Management Journal, 902(December 2009), 892-902. doi:10.1002/smj 
Tseng, C.-Y., Pai, D. C., \& Hung, C.-H. (2011). Knowledge absorptive capacity and innovation performance in KIBS. Journal of Knowledge Management, 15(6), 971-983. doi:10.1108/13673271111179316

Un, C. A. (2011). The advantage of foreignness in innovation. Strategic Management Journal, 32(11), 12321242.

Vasilchenko, E., \& Morrish, S. (2011). The Role of Entrepreneurial Networks in the Exploration and Exploitation of Internationalization Opportunities by Information and Communication Technology Firms. Journal of International Marketing, 19(4), 88-105.

Verona, G. (1999). A resource-based view of product development. Academy of Management Review, 24(1), $132-142$.

Wales, W., Parida, V., \& Patel, P. (2013). TOO MUCH OF A GOOD THING? ABSORPTIVE CAPACITY, FIRM PERFORMANCE, AND THE MODERATING ROLE OF ENTREPRENEURIAL ORIENTATION. Strategic Management Journal, 633(October 2012), 622-633. doi:10.1002/smj

Welch, D., \& Welch, L. (1996). The internationalization process and networks: a strategic management perspective. Journal of International Marketing, 4(3), 11-28.

Zahra, S. A., \& George, G. (2002). Absorptive capacity: A review, reconceptualization, and extension. Academy of management review, 17(2), 185-203.

Zou, S., Taylor, C., \& Osland, G. (1998). The EXPERF scale: a cross-national generalized export performance measure. Journal of International Marketing, 37-59. 


\section{APPENDIX}

Descriptive statistics

\begin{tabular}{lccccc}
\hline & N & Minimum & Maximum & Mean & Std. Deviation \\
\hline Experience (age/years) & 202 & 0 & 40 & 6.90 & 6.59 \\
Size (employees) & 202 & 0 & 1200 & 20.77 & 90.04 \\
PP - Past Performance & 202 & 1.00 & 5.00 & 4,36 & 0.74 \\
AC - Absorptive Capacity & 202 & 2.25 & 5.00 & 4.44 & 0.58 \\
PAC - Potential AC & 202 & 2.00 & 5.00 & 4.50 & 0.59 \\
RAC - Realized AC & 202 & 2.50 & 5.00 & 4.38 & 0.64 \\
IN - Innovativeness & 202 & 1.67 & 5.00 & 4.33 & 0.68 \\
Valid N & 202 & & & & \\
\hline
\end{tabular}

Correlation Matrix

\begin{tabular}{|c|c|c|c|c|c|c|c|}
\hline & PP & IN & PAC & RAC & IT & SZ & EX \\
\hline PP & 1 & & & & & & \\
\hline IN & $0.61^{* *}$ & 1 & & & & & \\
\hline PAC & $0.51^{* *}$ & $0.63^{* *}$ & 1 & & & & \\
\hline RAC & $0.55^{* *}$ & $0.66^{* *}$ & $0.95^{* *}$ & & & & \\
\hline IT & -0.01 &,- 05 &,- 033 & -0.01 & 1 & & \\
\hline$S Z$ & 0.13 &, $18^{* *}$ &, 13 & 0.10 &, $24^{* *}$ & 1 & \\
\hline EX & $-0.17^{*}$ &,$- 180^{*}$ &,$- 18^{*}$ & $-0.15^{*}$ &,- 021 &,- 12 & 1 \\
\hline
\end{tabular}

** Correlation is significant at the 0.01 level (2-tailed).

* Correlation is significant at the 0.05 level (2-tailed).

Questionnaire

Absorptive capacity

Potential AC

Employees and different sectors of our company share information that allows developing current and new products 0.68

Our company has systems, methods or tools to keep and manage information about clients, markets and technologies 0.63

$\begin{array}{ll}\text { Our company has employees trained to discuss and comprehend the clients' needs } & 0.62\end{array}$

$\begin{array}{lr}\text { Our company constantly analyze the possibility to adopt new technologies } & 0.56\end{array}$

Realized AC

Our company has resources (systems, tools, equipment) that allow it to improve its process 0.70

$\begin{array}{lr}\text { Our company promotes actions such as meetings and workshops to improve its process } & 0.52\end{array}$

$\begin{array}{ll}\text { Our company has employees trained to improve/develop current and new products } & 0.69\end{array}$

$\begin{array}{lc}\text { Our company has established routines to improve/develop current and new products } & 0.81\end{array}$

Innovativeness

Our company has capacity or propensity to introduce new ideas, process or technologies 0.64

In the last three years, our company has focused on innovation instead of current products and services 0.66

Our company stimulates the employees' commitment to creativity and innovation of the process 0.72

$\begin{array}{lr}\text { Our company offers formal training programs to qualify employees } & 0.64\end{array}$

$\begin{array}{lr}\text { Our company has reward mechanisms to value employees ideas } & 0.75\end{array}$

$\begin{array}{lr}\text { Our company encourages employees to make decisions in their activities and sectors } & 0.70\end{array}$

Past Performance

$\begin{array}{lc}\text { In the last three years, our company has increased its sales to new clients } & 0.57\end{array}$

$\begin{array}{lr}\text { In the last three years, our company has increased its productivity } & 0.84\end{array}$

$\begin{array}{lr}\text { In the last three years, our company has improved its competitiveness } & 0.77\end{array}$

In the last three years, our company has improved its strategic competitive positioning 0.84

In the last three years, our company has increased its market share 